
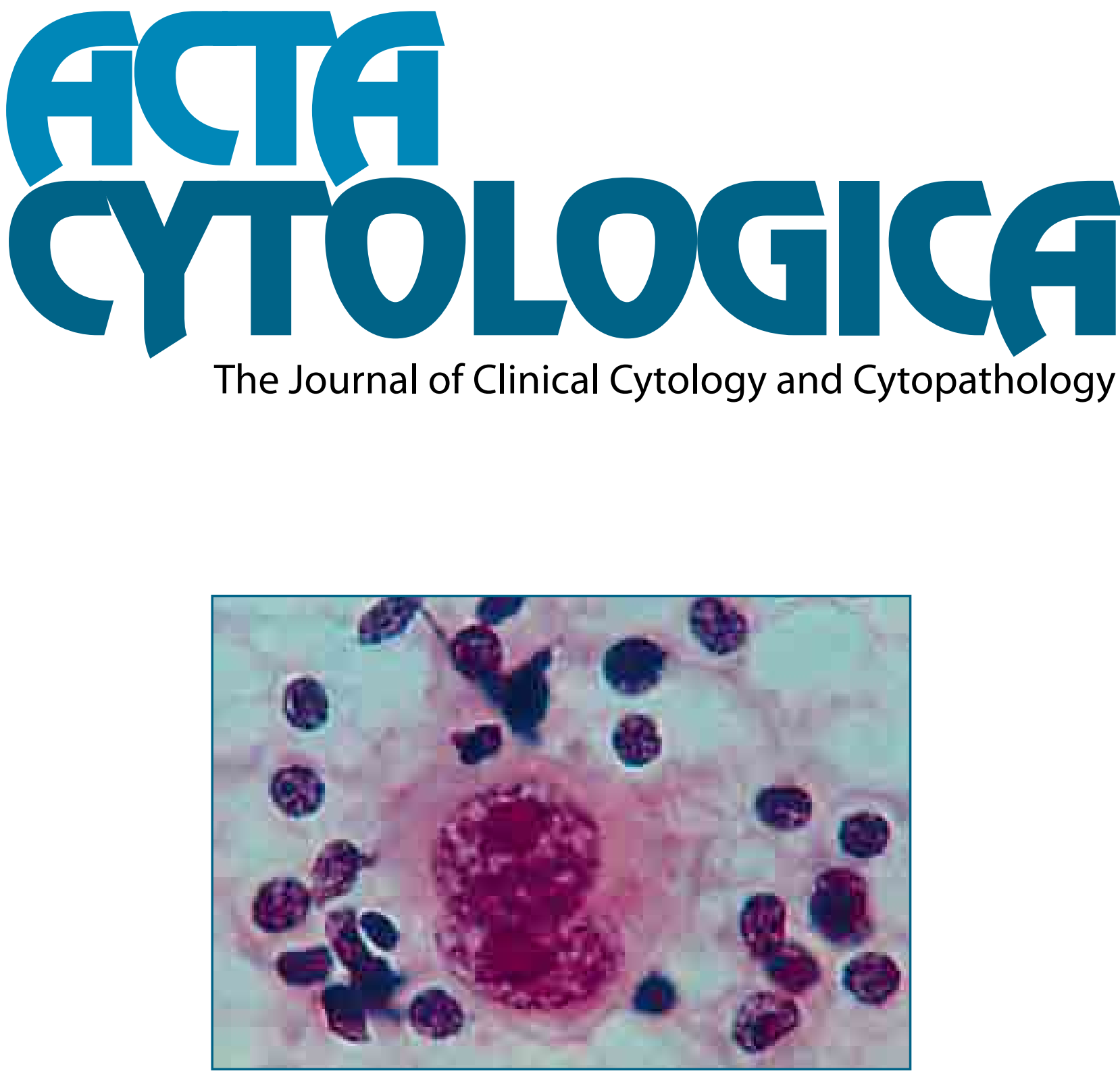


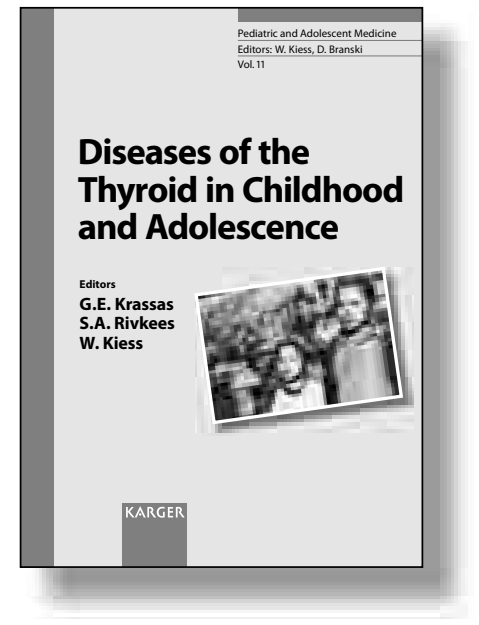

This volume presents the latest global knowledge of thyroid disorders in infancy, childhood, and adolescence and represents experience and views from a panel of the world's most renowned authorities on thyroid pathophysiology and clinical entities in the pediatric population. Both basic science and clinical aspects of thyroid disease are covered. Thyroid function, from ontogenesis and anatomy of the hypothalamic-pituitary-thyroid axis to thyroid and trace elements, is discussed. Topics include thyroid disease during pregnancy, iodine deficiency and excess, thyroid autoimmunity, hypo- and hyperthyroidism, thyroid related eye disease, and thyroid cancer

Authoritative and comprehensive, this book brings together the most current information available on the topic. It is an essential resource for pediatricians, endocrinologists, internists, neonatologists, family physicians, obstetricians and gynecologists looking for an insight into the pathophysiology, clinical presentation and treatment of thyroid disease in children and adolescents.

\section{Diseases of the Thyroid in Childhood and Adolescence}

\author{
Editors \\ Gerasimos E. Krassas \\ Scott A. Rivkees \\ Wieland Kiess
}

\section{Contents}

Preface: Krassas, G.E.; Rivkees, S.A.; Kiess, W.

Ontogenesis and Anatomy of the HypothalamicPituitary-Thyroid Axis: Tsoumalis, G.; Tsatsoulis, $\boldsymbol{A}$.

Thyroid Disease during Pregnancy: Lazarus, J.H.

Thyroid Function in the Newborn and Infant: Spiliotis, B.E.

Pediatric Aspects of Thyroid Function and lodine: Knobel, M.; Medeiros-Neto, G. Thyroid Hormone Transport and Actions: Feldt-Rasmussen, U.; Rasmussen, Å.K.

The Thyroid and Autoimmunity in Children and Adolescents: Weetman, A.P.

Congenital Hypothyroidism: Karges, B.; Kiess, W.

Newborn Screening, Hypothyroidism in Infants, Children and Adolescents: Büyükgebiz, A.

Resistance to Thyroid Hormone in Childhood: Bakker, 0.
Pendred Syndrome: Kassem, S.; Glaser, B.

Treatment of Hyperthyroidism Due to Graves'Disease in Children: Rivkees, s.A.

Thyroid-Associated Ophthalmopathy in Juvenile Graves' Disease: Clinical, Endocrine and Therapeutic Aspects: Krassas, G.E.; Gogakos, $A$.

Differentiated Thyroid Carcinoma in Pediatric Age: Wiersinga, W.M.

Imaging of the Normal and Affected Thyroid in Childhood: Bennedbæk, F.N.; Hegedüs, $\boldsymbol{L}$.

Thyroid and Other Autoimmune Diseases with Emphasis on Type 1 Diabetes Mellitus and Turner Syndrome: Kapellen, T.; Galler, A.; Pfäffle, R.; Kiess, W.

Thyroid and Trace Elements in Children and Adolescents: Kahaly, G.J.

Author Index

Subject Index

www.karger.com/pamed

Pediatric and Adolescent Medicine, Vol. 11 Series Editors: Kiess, W. (Leipzig); Branski, D. (Jerusalem) ISSN 1017-5989

Diseases of the Thyroid in Childhood and Adolescence

Editors: Krassas, G.E. (Thessaloniki); Rivkees, S.A. (New Haven, Conn.); Kiess, W. (Leipzig) VIII + 294 p., 62 fig. ( 6 in color), 42 tab., hard cover, 2007 CHF 216.- / EUR 154.50 / USD 216.00

Prices subject to change

EUR price for Germany, USD price for USA only ISBN 978-3-8055-8205-6
Please send: __ copy/ies

Postage and handling free with prepayment

E Payment:

- $\square$ Check enclosed $\square$ Please bill me

ᄂ Please charge to my credit card

$\square$ American Express $\quad \square$ Diners $\quad \square$ Eurocard

- $\square$ MasterCard $\quad \square$ Visa

- Card No

○

Exp. date:
Fax: +41 613061234

S. Karger AG, P.O. Box, CH-4009 Basel (Switzerland)

E-Mail orders@karger.ch, www.karger.com

Name/Address: 
Official Periodical of the International Academy of Cytology

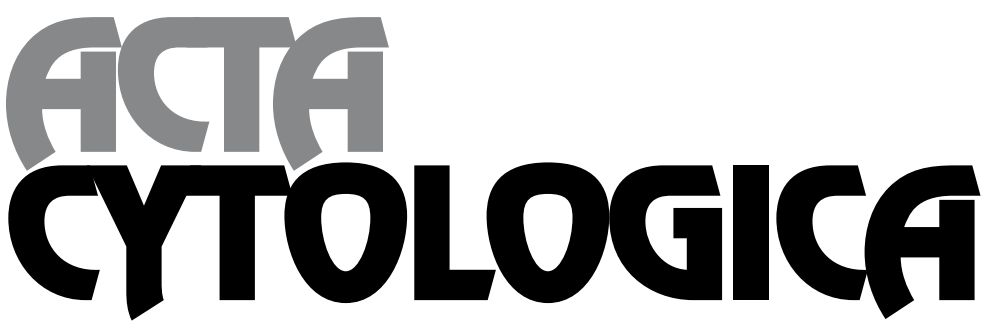

The Journal of Clinical Cytology and Cytopathology

Founded 1957 by Georg L. Wied, continued by Marluce Bibbo (since 2004)

\section{Editor-in-Chief}

Marluce Bibbo, Philadelphia, Pa.

\section{Associate Editors}

R. Marshall Austin, Pittsburgh, Pa. Thomas A. Bonfiglio, Rochester, N.Y. Lukas Bubendorf, Basel Edmund S. Cibas, Boston, Mass. Yener S. Erozan, Baltimore, Md. David B. Kaminsky, Palm Springs, Calif. Robert Y. Osamura, Tokyo
Fernando C. Schmitt, Porto Volker Schneider, Freiburg i.B. Mark E. Sherman, Rockville, Md. Diane Solomon, Rockville, Md. Alain P. Verhest, Brussels Philippe Vielh, Villejuif

\section{Editorial Board}

Fadi W. Abdul-Karim, Cleveland, Ohio Mousa A. Al-Abbadi, Dammam Syed Z. Ali, Baltimore, Md.

Karen M. Atkison, Burlington, N.C Ulrik Baandrup, Hjoerring Zubair W. Baloch, Philadelphia, Pa. George G. Birdsong, Atlanta, Ga. Beata Bode-Lesniewska, Zurich Mathilde E. Boon, Leiden Tien-Chun Chang, Taipei David Chhieng, New Haven, Conn. Brian T. Collins, St. Louis, Mo.

William N. Crabtree, Indianapolis, Ind. Peter Dalquen, Basel

Dilip K. Das, Safat

Jaroslava Dušková, Prague

Hormoz Ehya, Philadelphia, Pa.

Guido Fadda, Rome

William C. Faquin, Boston, Mass.

Annabelle Farnsworth, North Ryde, N.S.W.

Brendan T. Fitzpatrick, Camden, N.J.

Kim R. Geisinger, Winston-Salem, N.C.
Ricardo González-Cámpora, Seville Prabodh K. Gupta, Philadelphia, Pa. Raj K. Gupta, Wellington Michael Henry, Rochester, Minn. Yajue Huang, Philadelphia, Pa. Matias Jiménez-Ayala, Madrid Kusum Kapila, Kuwait Bryan Knight, Brisbane, Qld. Tadao K. Kobayashi, Shiga Hiroyuki Kuramoto, Kanagawa Gladwyn Leiman, Burlington, Vt. Oscar Lin, New York, N.Y.

Virginia A. LiVolsi, Philadelphia, Pa. Britt-Marie Ljung, San Francisco, Calif. Adhemar Longatto Filho, Braga Sue Ellen Martin, Los Angeles, Calif. Ravi Mehrotra, Allahabad Pamela M. Michelow, Johannesburg Dina R. Mody, Houston, Tx. Joseph F. Nasuti, Bridgeport, Conn. Wai-Kuen Ng, Hong Kong Ellen C. Obermann, Basel N. Paul Ohori, Pittsburgh, Pa.
Torill Sauer, Oslo

Spasenija Savic, Basel José P. Schalper, Concepcion Jan F. Silverman, Pittsburgh, Pa. Lambert Şkoog, Stockholm Charalambos C. Solomides, Philadelphia, $\mathrm{Pa}$. Mark H. Stoler, Charlottesville, Va. Kari J. Syrjänen, Turku Edneia M. Tani, Stockholm Gary Tse, Hong Kong László Vass, Kistarcsa David C. Wilbur, Boston, Mass. Bin Yang, Cleveland, Ohio Grace C. H. Yang, New York, N.Y. Nancy A. Young, Philadelphia, Pa. Maureen F. Zakowski, New York, N.Y. Pio Zeppa, Naples

National and Regional Editors (listed on next page)
Printed in Switzerland on acid-free and non-aging paper (ISO 9706) by Reinhardt Druck, Basel
Appears bimonthly: 1 volume per year (6 issues) 


\section{National and Regional Societies and Editors}

\section{CYTOLOGICA}

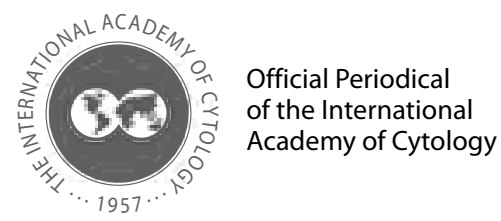

\section{International Editor}

Marluce Bibbo

The journal is also the official periodical of the following

\section{National and Regional Societies}

\section{National and Regional Editors}

Albanian Society of Cytology.

Majlinda Buba Ikonomi

Australian Society of Cytology Andrew S. Field

Société Belge de Cytologie Clinique/Belgische Vereniging voor Klinische Cytologie . . Claire Bourgain

Sociedade Brasileira de Citopatologia . . . . . . . . . . . . . . . . . Álvaro Piazzeta Pinto

British Society for Cytopathology . . . . . . . . . . . . . . . . . Karin Denton

The Canadian Society of Cytology/Société Canadienne de Cytologie . . . . . . . . . Karim Khetani

Ceská spolecnost pro klinickou cytologii . . . . . . . . . . . . . . . . . . Jaroslava Dušková

Sociedad Chilena de Citologia . . . . . . . . . . . . . . . . . . . . . . . . . . . . . . . . . . . . . . . . . . .

Chinese Society of Cytopathology . . . . . . . . . . . . . . . . . . . Dongge Liu

Asociacion Colombiana de Citologia . . . . . . . . . . . . . . . . . . Lilia M. Osorio Mejia de Gomez

Croatian Society for Clinical Cytology . . . . . . . . . . . . . . . . . . Vesna Mahovlić

Danish Society of Pathologic Anatomy and Clinical Cytology . . . . . . . . . . . . Doris Schledermann

Deutsche Gesellschaft für Zytologie . . . . . . . . . . . . . . . . . . . Dietmar Schmidt

Dutch Society of Pathology . . . . . . . . . . . . . . . . . . . . . . . Elle K.J. Risse

European Federation of Cytological Societies. . . . . . . . . . . . . . . Philippe Vielh

Sociedad Española de Citologia . . . . . . . . . . . . . . . . . . . . . . . Mercedes Santamaría Martínez

Finnish Society of Clinical Cytology . . . . . . . . . . . . . . . . . . Leena Krogerus

La Société Française de Cytologie Clinique . . . . . . . . . . . . . . . . . . . . . . . . . . . . cécile Vacher Lavenu

Hellenic Society of Clinical Cytology . . . . . . . . . . . . . . . . . . Ekatreini Politi

Hong Kong Society of Cytology . . . . . . . . . . . . . . . . . . . Ui-Soon Khoo

Magyar Pathologusok Tarsasaga-Cytodiagnosztikai Sectio . . . . . . . . . . . . . . . László Vass

Indian Academy of Cytologists . . . . . . . . . . . . . . . . . . . . Arvind Rajwanshi

Iranian Society of Clinical Cytology . . . . . . . . . . . . . . . . . Mansour Mehzad

Società Italiana di Citologia . . . . . . . . . . . . . . . . . . . . Patricia Maioli

Società Italiana di Anatomia Patologica Citodiagnostica . . . . . . . . . . . . . . Sonia Prandi

Japanese Society of Clinical Cytology . . . . . . . . . . . . . . . . . . . . . Yukitoshi Satoh

Kazakhstan Association of Clinical Cytologists. . . . . . . . . . . . . . . . . . Azat I. Shibanova

Korean Society for Cytopathology . . . . . . . . . . . . . . . . . . . . . . . . . . . . . . . . . . . . . . . . Jin

Sociedad Latino-Americana de Citología . . . . . . . . . . . . . . . . . . . José P. Schalper

Mexican Academy of Cytopathology. . . . . . . . . . . . . . . . . . . . . Oralia Barboza Quintana

New Zealand Society of Cytology . . . . . . . . . . . . . . . . . . Peter N.G. Fitzgerald

Norsk Forening for Klinisk Cytologi . . . . . . . . . . . . . . . . . . Aasmund Berner

Österreichische Gesellschaft für Angewandte Zytologie . . . . . . . . . . . . . . . Helene G. Wiener

Sociedad Peruana de Citologia . . . . . . . . . . . . . . . . . . . . Delia M. Jara Facundo

Sociedade Portuguesa de Citologia. . . . . . . . . . . . . . . . . . Fernando C. Schmitt

Romanian Society of Cytology . . . . . . . . . . . . . . . . . . . . Irina Ecaterina Julea

Russian Association of Clinical Cytologists . . . . . . . . . . . . . . . Naum A. Shapiro

Schweizerische Gesellschaft für Klinische Cytologie . . . . . . . . . . . . . . . . . Lukas Bubendorf

Slovenian Society of Clinical Cytology. . . . . . . . . . . . . . . . . . . . Alenka Repse Fokter

Suid-Afrikaanse Vereniging vir Kliniese Sitologie/

South African Society of Clinical Cytology . . . . . . . . . . . . . . . . Pamela M. Michelow

Svensk Förening för Klinisk Cytologi ․ . . . . . . . . . . . . . . . . . Edneia M. Tani

Society of Clinical Cytology Taiwan . . . . . . . . . . . . . . . . . . . Ming-Shyan Huang

Turkish Society of Cytopathology . . . . . . . . . . . . . . . . . . . . Binnur Önal

Sociedad Uruguaya de Citologia . . . . . . . . . . . . . . . . . . . . . Carmen Alvarez-Santín

West African Society of Cytology . . . . . . . . . . . . . . . . Jaiyeola Thomas

\section{KARGER}

Fax +41613061234

E-Mail karger@karger.ch

www.karger.com 


\section{$37^{\text {th }}$ European \\ Congress of Cytology}

Dubrovnik-Cavtat, Croatia

$30^{\text {th }}$ September $-3^{\text {rd }}$ October 2012

\section{Hotel "Croatia" Conference Centre}

\section{Organized by}

Croatian Society for Clinical Cytology of Croatian Medical Association on behalf of the European Federation of Cytology Societies secretariat@cytology2012.com

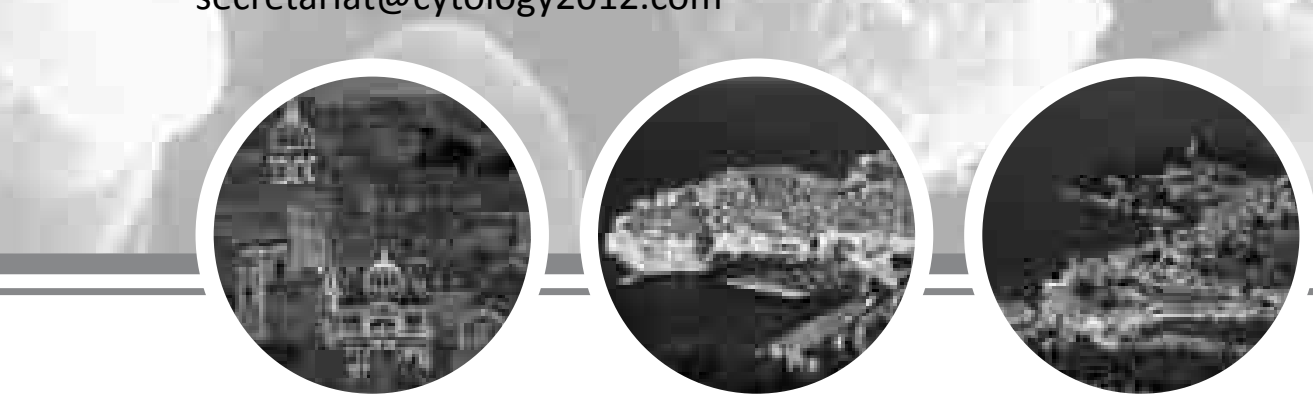

MAIN TOPICS

Analytical Cytology

- Cytogenetics

- Flow cytometry

- Image analysis

- Immunocytochemistry

- Molecular cytology

Breast cytology

Cancer immunology

Cytology of infectious diseases

Cytotechnology

Forensic cytology

GI tract, liver, pancreas, EUS, FNA from deep-seated masses

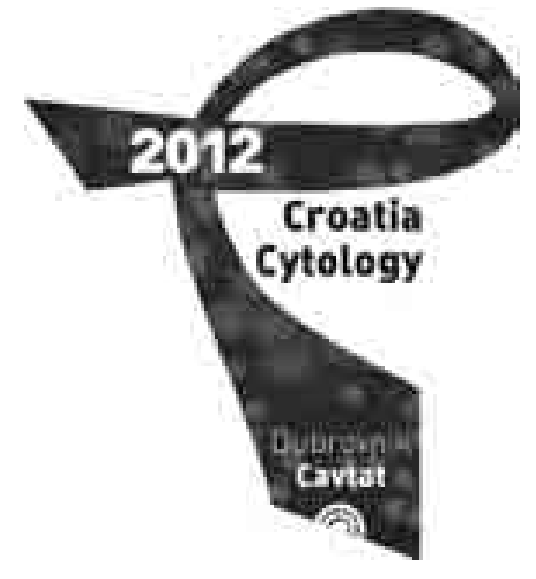

Gynecologic cytology (cervix, endometrium, ovary, vulva), HPV

Head and neck FNA

Hematopoietic system cytology (lymph nodes and bone marrow)

Intraoperative and interventional cytology

Pediatric cytology

Quality assurance and automation

Respiratory cytology

Resident's session

Serous fluid cytology, cerebrospinal fluid cytology

Soft tissue and bone FNA

Technical organizer

Tele-cytology

Training programs for cytologist and cytotechnologist

Transplant cytology

Thyroid FNA

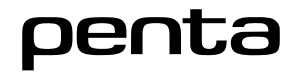

Urinary cytology

Veterinary cytology

Free topics 
Acta Cytologica is a bimonthly published journal that aims to cover all aspects within the area of both clinical cytology and cytopathology. It furthers the understanding of cytopathologic processes and facilitates the translation of current research into clinical practice. As the official journal of the International Academy of Cytology and affiliated to over 50 cytology societies around the world, Acta Cytologica evaluates new and existing diagnostic applications of scientific advances as well as their clinical correlation. The journal features Original Papers (Fine Needle Aspiration, Gynecologic Cytopathology, Nongynecologic Cytopathology, Techniques, Molecular Techniques), Novel Insights from Clinical Practice (formerly Case Reports), Letters to the Editor and Reviews. Criteria for acceptance are quality, originality, and clarity. Acta Cytologica will not consider papers that are either preliminary or purely descriptive. Reports on clinical cases are accepted only if they provide novel insight into unresolved problems of cytology and cytopathology. All articles are subject to editorial review.

\section{Submission}

Only original papers written in English are considered. Manuscripts should be submitted online using the online submission website at www.karger.com/acy (the preferred word-processing package is MSWord $\left.{ }^{\circledR}\right)$. Before submitting your manuscript, you are encouraged to review the detailed guidelines at www.karger.com/ acy_guidelines for specific directions as how to get a manuscript ready for submission. If you should have any problems with your submission, please contact the editorial office:

Marluce Bibbo, MD

S. Karger AG

Editorial Office 'Acta Cytologica'

P.O. Box

CH-4009 Basel (Switzerland)

Tel. +4161306 1357

Fax. +41613061434

E-Mail acy@karger.ch

\section{Conditions}

All manuscripts must be accompanied by a covering letter signed on behalf of all authors verifying that all the authors were active participants. Assurance should be given that the manuscript is original and not under simultaneous consideration for publication in another journal. Please provide complete financial disclosure information. Presentation of manuscripts should conform with the Uniform Requirements for Manuscripts Submitted to Biomedical Journals (see N Engl J Med 1997;336:309-315). All articles will undergo an in-depth peer-review process. Submission of an article for publication implies the transfer of the copyright from the author to the publisher upon acceptance. Accepted papers become the permanent property of Acta Cytologica and may not be reproduced by any means, in whole or in part, without the written consent of the publisher. It is the authors' responsibility to obtain permission to reproduce illustrations, tables, etc. from other publications. Signed permission forms from the copyright holders and original authors for all previously published tables or figures must be provided.

\section{Sections}

Original Paper (Fine Needle Aspiration, Gynecologic Cytopathology, Nongynecologic Cytopathology, Techniques, Molecular Techniques): Submitted manuscripts should be fully documented reports of original research. They must describe significant and original observations.
Review: Potential authors are asked to contact the Editor-in-Chief before submitting a paper in order to avoid clashes with other pending reviews.

Letter to the Editor: Letters to the Editor concerning articles published in Acta Cytologica may be submitted for publication. They should not be more than one printed page in length. If accepted, the authors of the articles concerned will be given the opportunity to reply.

Novel Insights from Clinical Practice (formerly Case Reports): the publication space available for case reports is very limited. The journal only considers case reports with significant new insights or with an extremely unusual and memorable course. Highlighted boxes containing one or two bullet points on 'Established facts' (what is already known) and 'Novel insights' (what new information has been gained) are required and should be placed on the first page of the report. These should be selected so as to reinforce the novelty of the clinical observation.

\section{Arrangement}

General: Manuscripts should be written in English and be as concise as possible. The length of the text should be limited to approximately 3,000 words, pages numbered consecutively, starting with the title page, and continuing in the following order: abstract and key words, body of text, references, figure legends and tables. Use generic names of drugs when possible. For any trade name cited, capitalize the first letter, and include the manufacturer's name and location (city, state/province, country). Express weights and measures in metric values. Acknowledge any presentation at a national or international medical society and any substantive financial support.

Title page: The first page of each paper should indicate the title, the authors' names, the institute(s) where the work was conducted, and a short title for use as running head. Limit the number of authors to 6 . If more than 6 authors contributed significantly to the article, the editorial of fice will consider including their names upon request.

Full address: The exact postal address of the corresponding author complete with postal code must be given at the bottom of the title page. Please also supply phone and fax numbers, as well as an e-mail address.

Key words: For indexing purposes, a list of 3-10 key words in English is essential.

Abstract: Each paper needs an abstract limited to 200 words structured as follows: Objective, Study design, Results and Conclusions. For Novel Insights from Clinical Practice the headings should be: Background, Case and Conclusion. Address the study's power to detect a difference if the research identified important variables that lacked a statistically significant difference.

Footnotes: Footnotes should be avoided. When essential, they are numbered consecutively and typed at the foot of the appropriate page.

Materials and Methods: Acknowledge that the original research was approved by the local institutional review board. Clearly state the method of any randomization, blinding and selection of specific statistical tests. Explain dropouts/exclusions and confounding variables.

Tables and illustrations: Tables and illustrations (both numbered in Arabic numerals) should be prepared on separate pages. Tables require a heading and figures a legend, also prepared on a separate page. Due to technical reasons, figures with a screen background should not be submitted. When possible, group several illustrations in one block for reproduction (max. size $1803223 \mathrm{~mm}$ ) or provide crop marks. Each illustration must be labelled with its number and the first author's name. Electroni- cally submitted b/w half-tone and color illustrations must have a final resolution of 300 dpi after scaling (final size), line art drawings one of $800-1,200$ dpi. Do not modify a low-resolution image by increasing the dpi. Figure files should not be embedded in a document file but submitted separately. All illustrations must include the original magnification and the stain employed, and clearly identify critical areas of radiographs, photomicrographs, etc. Provide sufficient information for a table to stand alone. Avoid tables in which the data could be included in the text in a few sentences.

References: In the text identify references by Arabic numerals [in square brackets]. Material submitted for publication but not yet accepted should be noted as 'unpublished data' and not be included in the reference list. The list of references should include only those publications which are cited in the text. In general, avoid listing unpublished data or manuscripts, personal communications, web sites and non-peer-reviewed publications. Do not alphabetize; number references in the order in which they are first mentioned in the text. The surnames of the authors followed by initials should be given. There should be no punctuation other than a comma to separate the authors. Preferably, please cite all authors. Abbreviate journal names according to the Index Medicus system. Also see International Committee of Medical Journal Editors: Uniform requirements for manuscripts submitted to biomedical journals (www.icmje.org). Authors using EndNote ${ }^{\circledR}$ may choose the format setting for Intervirology for the correct format of references.

Examples

(a) Papers published in periodicals: Vilhelmsson M, Johansson C, Jacobsson-Ekman G, Crameri R, Zargari A, Scheynius A: The malassezia sympodialis allergen Mala s 11 induces human dendritic cell maturation, in contrast to its human homologue manganese superoxide dismutase. Int Arch Allergy Immunol 2007;143:155-162. (b) Papers published only with DOI numbers: Theoharides TC, Boucher W, Spear K: Serum interleukin-6 reflects disease severity and osteoporosis in mastocytosis patients. Int Arch Allergy Immunol DOI: 10.1159/000063858. (c) Monographs: Matthews DE, Farewell VT: Using and Understanding Medical Statistics, ed 4, revised. Basel, Karger, 2007.

(d) Edited books: Park BK, Sanderson JP, Naisbitt DJ: Drugs as haptens, antigens, and immunogens; in Pichler WJ (ed): Drug Hypersensitivity. Basel, Karger, 2007, pp $55-65$.

\section{Color Illustrations}

For all manuscripts accepted, authors will be charged CHF 500.00 for each color page published in the print version of the journal. Several color illustration may be placed onto one color page. When the illustration appears in black and white in the printed version, the authors will not be charged a fee. In the online version all figures submitted in color will appear in color at no charge to the author. Referring to colors in the text and figure legends should be avoided. We recommend using symbols, instead of color, for charts and graphs.

\section{Ethics}

Published research must comply with the guidelines for human studies and animal welfare regulations. Authors should state that subjects have given their informed consent and that the study protocol has been approved by the institute's committee on human research and thus meets the standards of the Declaration of Helsinki in its revised version of 1975 and its amendments of 1983, 1989, and 1996 [JAMA 1997;277:925-926]. Information suitable to

\section{KARGER}

Fax +4161306 1234

E-Mail karger@karger.ch

www.karger.com 
reveal the subject's identity is to be avoided. Further, authors should also state that animal experiments conform to institutional standards. Copies of these guidelines and policy statements must be available for review by the editors if necessary.

\section{Conflict of Interest}

All forms of funding and support, including that from companies, as well as any potential competing financial interests should be acknowledged in the cover letter to the editors when applicable. The statement has to be listed at the end of the article.

\section{Digital Object Identifier (DOI)}

S. Karger Publishers supports DOIs as unique identifiers for articles. A DOI number will be printed on the title page of each article. DOIs can be useful in the future for identifying and citing articles published online without volume or issue information. More information can be found at www.doi.org.

\section{Supplementary Material}

Supplementary material is restricted to additional data that are not necessary for the scientific integrity and conclusions of the paper. Please note that all supplementary files will undergo editorial review and should be submitted together with the original manuscript. The Editors reserve the right to limit the scope and length of the supplementary material. Supplementary material must meet production quality standards for Web publication without the need for any modification or editing. In general, supplementary files should not exceed $10 \mathrm{MB}$ in size. All figures and tables should have titles and legends and all files should be supplied separately and named clearly. Acceptable files and formats are: Word or PDF files, Excel spreadsheets (only if the data cannot be converted properly to a PDF file), and video files (.mov, .avi, .mpeg).

\section{Author's Choice ${ }^{\mathrm{TM}}$}

Karger's Author's Choice ${ }^{\mathrm{TM}}$ service broadens the reach of your article and gives all users worldwide free and full access for reading, downloading and printing at www. karger.com. The option is available for a onetime fee of CHF 3000.-, which is a permissible cost in a grant allocation. More information can be found at www.karger. com/authors_choice.

\section{NIH-Funded Research}

The U.S. National Institutes of Health (NIH) mandates under the NIH Public Access Policy that final, peer-reviewed manuscripts appear in its digital database within 12 months of the official publication date. As a service to authors, Karger submits the final version of your article on your behalf to PubMed Central. For those selecting our premium Author's Choice ${ }^{\mathrm{TM}}$ service, we will send your article immediately upon publishing, accelerating the accessibility of your work without the usual embargo. More details on NIH's Public Access Policy is available at http://publicaccess.nih.gov/FAQ.htm\#a1.

\section{Self-Archiving}

Karger permits authors to archive their pre-prints (i.e. pre-refereeing) or post-prints (i.e. final draft post-refereeing) on their personal or institution's servers, provided the following conditions are met: Articles may not be used for commercial purposes, must be linked to the publisher's version, and must acknowledge the publisher's copyright. Authors selecting Karger's Author's Choice ${ }^{\mathrm{TM}}$ feature, however, are also permitted to archive the final, published version of their article, which includes copyediting and design improvements as well as citation links.

\section{Copy Editing}

All manuscripts accepted for publication by Karger are subject to copy editing. Changes introduced by the copy editor and/or questions will be marked in the manuscript so please be sure to check the proofs against the manuscript. The copy edited manuscript will be returned along with the proofs.

\section{Proofs}

Unless indicated otherwise, proofs are sent to the corresponding author and should be returned with the least possible delay. Alterations made in proofs, other than the correction of printer's errors, are charged to the author. No page proofs are supplied.

\section{Reprints}

An order form and a price list are sent with the proofs. Orders submitted after the release of an article in print are subject to considerably higher prices.

\section{'A collection of extraordinary essays'}

\section{GOTTFRIED SCHATZ \\ A MATTER OF WONDER}

\section{What Biology Reveals about Us, Our World, and Our Dreams}

Where do we come from? Is our destiny determined by the genes we inherit? In this book Gottfried Schatz, the world-renowned biochemist and co-discoverer of mitochondrial DNA, gives lucid - albeit often surprising - answers to universal questions and takes the reader on a fascinating journey of discovery across the boundaries of scientific disciplines. With passion and a keen sense of wonder he draws on philosophy, cultural history and art to formulate his reflections on the mysteries of life. His essays will appeal not only to scientists but to all inquisitive minds, regardless of educational and professional background.

\section{KARGER \\ S. Karger AG, P.O. Box \\ $\mathrm{CH}-4009$ Basel \\ (Switzerland) \\ Fax +41613061234 E-Mail orders@karger.ch www.karger.com}

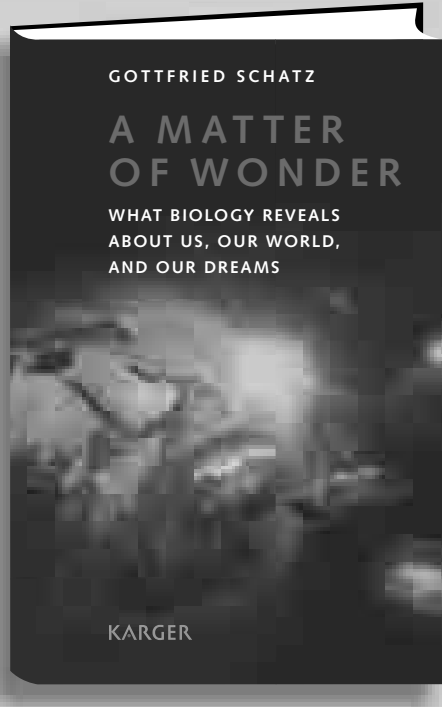

G. Schatz (Basei)

\section{A Matter of Wonder}

What Biology Reveals about Us,

Our World, and Our Dreams

Translated by A. Shields

XII + 190 p., 2 color fig., hard cover, 2011

CHF 29.-/ EUR 21.50/USD 29.00

ISBN 978-3-8055-9744-9

More information and sample essays at www.karger.com/schatz 
ISSN Print Edition: 0001-5792

ISSN Online Edition: 1421-9662

Journal Homepage: www.karger.com/acy

Publication Data: 'Acta Cytologica' is published 6 times a year. Volume 56 with 6 issues appears in 2012 .

Copyright: () 2012 S. Karger AG, Basel (Switzerland). All rights reserved. No part of this publication may be translated into other languages, reproduced or utilized in any form or by any means, electronic or mechanical, including photocopying, recording, microcopying, or by any information storage and retrieval system, without permission in writing from the publisher or, in the case of photocopying, direct payment of a specified fee to the Copyright Clearance Center.

Disclaimer: The statements, opinions and data contained in this publication are solely those of the individual authors and contributors and not of the publisher and the editor(s). The appearance of advertisements in the journal is not a warranty, endorsement, or approval of the products or services advertised or of their effectiveness, quality or safety. The publisher and the editor(s) disclaim responsibility for any injury to persons or property resulting from any ideas, methods, instructions or products referred to in the content or advertisements.
Subscription Rates: Subscriptions run for a full calendar year. Prices are given per year.

Personal subscription:

CHF 366.- $\quad$ CHF 414.

EUR 293.- EUR 331.

USD $355.00 \quad$ USD 402.00

postage and handling (added to print and print+online)

CHF 40.80 Europe, CHF 60.- Overseas

EUR 31.20

USD 56.40

Institutional subscription:

Print or Online

Print+Online combined

CHF 731.-

CHF 804.-

EUR 585.-

EUR 643.-

USD 781.00

postage and handling (added to print and print+online)

CHF 51.- Europe, CHF 75.- Overseas

EUR 39.00

USD 70.50

Airmail surcharge: CHF 51.- / USD 48.00

Discount subscription prices:

- Members of the International Academy of

Cytology (IAC)

- Members of the American Society of

Cytopathology (ASC)
Back Volumes and Single Issues: Information on availability and prices of single print issues and print or electronic back volumes can be obtained from Customer Service at service@karger.ch.

Bibliographic Indices: This journal is regularly listed in bibliographic services, including Current Contents ${ }^{\circledR}$ and PubMed/MEDLINE.

Photocopying: This journal has been registered with the Copyright Clearance Center (CCC), as indicated by the code appearing on the first page of each article. For readers in the US, this code signals consent for copying of articles for personal or internal use, or for the personal or internal use of specific clients, provided that the stated fee is paid per copy directly to

Copyright Clearance Center Inc.

222 Rosewood Drive

Danvers, MA 01923 (USA)

A copy of the first page of the article must accompany payment. Consent does not extend to copying for general distribution, for promotion, for creating new works, or for resale. In these cases, specific written permission must be obtained from the copyright owner,

S. Karger AG, P.O. Box

CH-4009 Basel (Switzerland).
Subscription Orders:

Orders can be placed at agencies,

bookstores, directly with the Publisher

\section{S. Karger AC}

Medical and Scientific Publishers

P.O. Box

CH-4009 Basel

Switzerland

(for courier services only:

Allschwilerstrasse 10

$\mathrm{CH}-4055$ Basel)

t: +41613061111

f: +41613061234

e: karger@karger.ch

w: www.karger.com or further Karger offices

or representatives:

Germany

S. Karger GmbH

Postfach

79095 Freiburg

Deutschland

(Hausadresse: Wilhelmstrasse 20A

79098 Freiburg)

$\mathrm{t}: \quad+49761452070$

f: +497614520714

e: information@karger.de

w: www.karger.de

\section{Japan}

Karger Japan, Inc

Shiba Daimon Asahi Bldg. 2F

1-2-23 Shiba Daimon

Minato-ku

Tokyo 105-0012

Japan

t: +81364356242

f: +81364356244

e: publisher@karger.jp

w: www.karger.jp

Change of Address:

Both old and new address should be sent

to the subscription source.

USA

S. Karger Publishers, Inc.

26 West Avon Road

P.O. Box 529

Unionville, CT 06085

USA

Toll free: +18008285479

t: +18606757834

f: +18606757302

e: karger@snet.net

France

Librairie Médi-Sciences Sarl

36, bd de Latour-Maubourg

75007 Paris

France

t: $+33(0) 145514258$

f: $+33(0) 145560780$

f: librairie@medi-sciences.fr

w: www.medi-sciences.fr

Gulf Council Countries, Iran,

Middle East, North Africa, Turkey

Trans Middle East International

Distribution Co. Ltd.

KaSha

Special Free Zone Area

Al Tunaib - Al Sikaah Al Sharq

P.O. Box 827, Code 11621 Khraibet Alsouq

Amman 11621

Jordan

t: +96265153467

f: +96265153472

e: info@kasha.cc

w: www.KaShaonline.com
South East Asia, China and Taiwan Karger Regional Office (Malaysia)

CEO Suite Kuala Lumpur

Quill 7, 27th Floor

Jalan Stesen Sentral 5

KL Sentral

Kuala Lumpur 50470

Malaysia

t: +60327766803

f: +60327766999

e: service@karger.cn; r.chew@karger.cn

\section{Karger China}

10th Floor, Twin Towers (East)

B12 Jianguomenwai Avenue

Beijing 100022

China

t: +861051235033

f: +861051235122

e: service@karger.cn; r.chew@karger.cn

w: www.karger.cn

India, Bangladesh, Sri Lanka

Medscience India

Plot No. 17, Yusuf Sarai Market

B.L. Glass Building, 2nd Floor

Sri Aurobindo Marg

New Delhi 110016

India

t: +911146029633

f: +911146029634

c: +919891052128

e: medsci.india@gmail.com

\section{KARGER}

Fax +41 613061234

E-Mail karger@karger.ch

www.karger.com
(C) 2012 S. Karger AG, Basel

The Journal Home Page is available at:

www.karger.com/acy 


\section{Contents}

See the journal website for contents

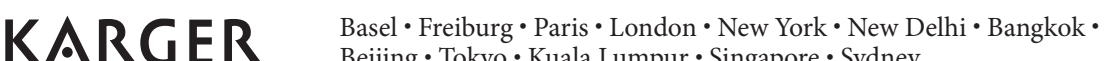
Beijing $\cdot$ Tokyo $\cdot$ Kuala Lumpur $\cdot$ Singapore $\cdot$ Sydney 


\section{Thoroughly updated 2nd edition \\ of this highly recommended book}

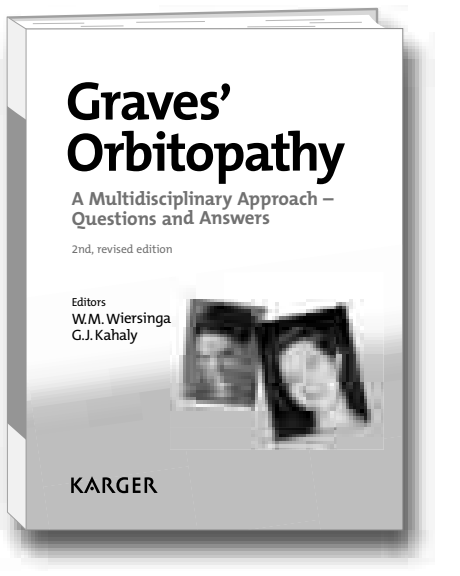

The significant progress in the understanding of the pathogenesis and the treatment of Graves' orbitopathy (GO) has warranted a second edition of this book within three years of the first. Now also fully incorporated is the EUGO$\mathrm{GO}$ consensus statement on management of $\mathrm{GO}$, which since has been accepted worldwide as a useful guideline. Furthermore all chapters have been thoroughly updated. Subjects covered include the pathology of GO and the controversial views on its pathogenesis; assessment of changes using reliable measuring techniques; medical management of GO including established and alternative treatment options; technical explanations and illustrations of various surgical procedures and finally, the molecular, immunologic, and clinical aspects of this complex disorder. Two new chapters have been added: one describing the socioeconomic impact of the disease and the other outlining the Amsterdam Declaration on Graves' Orbitopathy.

The successful question-and-answer format facilitates its use as a reference guide for medical practitioners and surgeons working in the fields of ophthalmology, internal medicine, endocrinology, pediatrics, immunology, as well as otorhinolaryngology.

\section{Graves' Orbitopathy \\ A Multidisciplinary Approach - Questions and Answers}

2nd, revised edition

\author{
Editors \\ Wilmar M. Wiersinga \\ Georges J. Kahaly
}

\section{Contents}

Preface to the 2nd, Revised Edition: Wiersinga, W.M.; Kahaly, G.J.

Preface to the 1st Edition: Wiersinga, W.M.; Kahaly, G.J.

\section{Diagnosis and Pathogenesis}

Clinical Manifestations: Dickinson, A.J.

Orbit-Thyroid Relationship: Lazarus, J.H.; Marino, $M$.

Epidemiology: Daumerie, $C$.

Pathogenesis: Orgiazzi, J.; Ludgate, $M$.

Orbital Imaging: Pitz, $\mathbf{S}$.

Diagnosis and Differential Diagnosis of Graves' Orbitopathy: Mourits, M.P.

Natural History: Pearce, S.; Kendall-Taylor, P.

\section{Management}

General Management Plan: Boboridis, $\boldsymbol{K}$; Perros, $\boldsymbol{P}$.

Combined Thyroid-Eye Clinics: Wiersinga, W.M. Thyroid Treatment: Marcocci, C.; Pinchera, $A$. Management of Mild Graves' Orbitopathy: Salvi, M.; Currò, $N$.
Management of Moderately Severe Graves' Orbitopathy: Kahaly, G.J.

Management of Very Severe Graves' Orbitopathy (Dysthyroid Optic Neuropathy): Lane, C.M.; Boschi, A.

Rehabilitative Surgery: Baldeschi, $L$.

Orbital Decompression: Baldeschi, $L$. Eye Muscle Surgery: $\mathbf{N a r d i}, \boldsymbol{M}$.

Eyelid Surgery: Neoh, C.; Eckstein, A.

\section{Miscellaneous Issues}

Quality of Life: Wiersinga, W.M.

Socioeconomic Impact: Kahaly, G.J.

Atypical Manifestations: von Arx, $\boldsymbol{G}$.

Childhood Graves' Orbitopathy: Krassas, G.E.

Prevention: Bartalena, $L$.

Future Developments: Salvi, M.; Baldeschi, $L$.

The Amsterdam Declaration on Graves' Orbitopathy: Perros, $P$.

Historical Notes on Graves' Disease: Mourits, M.P.

Author Index Subject Index

www.karger.com

Graves' Orbitopathy
A Multidisciplinary Approach - Questions and Answers

2nd, revised edition

Editors: Wiersinga, W.M. (Amsterdam)

Kahaly, G.J. (Mainz)

$\mathrm{XVI}+286$ p., 95 fig., 53 in color, 41 tab., soft cover, 2010

CHF 159.- / EUR 133.- / USD 187.00

Prices subject to change

EUR price for Germany, USD price for USA only

ISBN 978-3-8055-9531-5

e-ISBN 978-3-8055-9532-2

\section{Please send: __ copy/ies}

Postage and handling free with prepayment

E Payment:

Please charge to my credit card

- $\square$ American Express $\square$ Diners $\quad \square$ Eurocard

ᄂ $\square$ MasterCard $\square$ Visa

- Card No.

$\boldsymbol{\sigma}$

Exp. date:

CVV/CVC

( 3 digits in the signature field on the back of Visa and MasterCard)

$\square$ Check enclosed $\square$ Please bill me

Orders may be placed with any bookshop, subscription agency, directly with the publisher or through a Karger distributor.
Fax: +41 613061234

S. Karger AG, P.O. Box, CH-4009 Basel (Switzerland)

E-Mail orders@karger.ch, www.karger.com

Name/Address: 


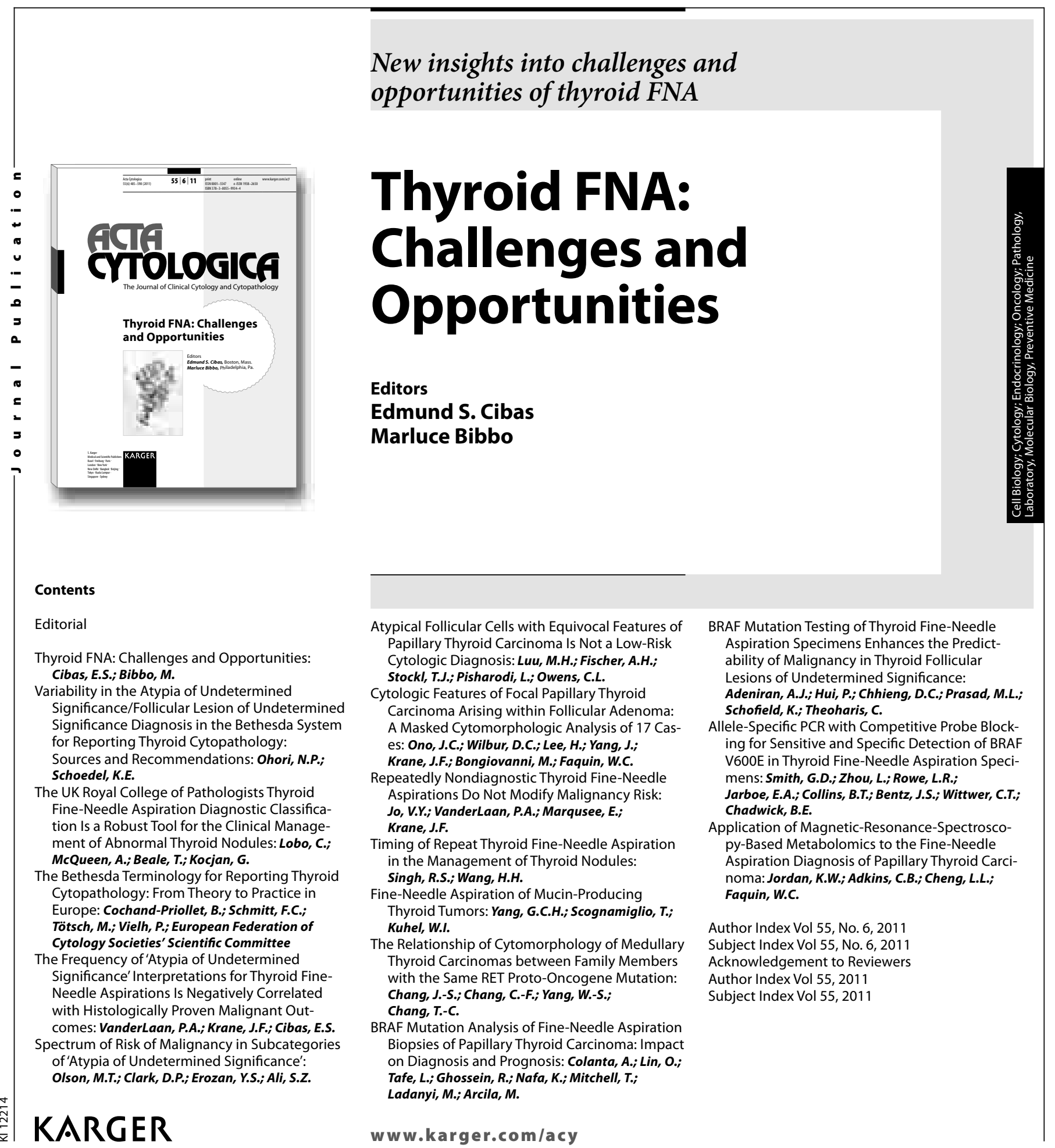

\section{Thyroid FNA: Challenges and} Opportunities

Editors: Cibas, E.S. (Boston, Mass.);

Bibbo, M. (Philadelphia, Pa.)

114 p., 34 fig., 24 in color, 44 tab., soft cover, 2011

CHF 39.- / EUR 33.- / USD 46.00

Prices subject to change

EUR price for Germany, USD price for USA only

ISBN 978-3-8055-9934-4

e-ISBN 978-3-8055-9935-1

\section{Special Topic Issue:}

Acta Cytologica

Vol. 55, No. 6 (2011)

Included in subscription

\section{- Please send: __ copy/ies}

Postage and handling free with prepayment

E

Payment:

Please charge to my credit card

- $\square$ American Express $\square$ Diners

ᄂ $\square$ MasterCard $\square$ Visa

- Card No

๑

ర Exp.date

-

- $\mathrm{CVV} / \mathrm{CVC}$

( 3 digits in the signature field on the back of Visa and MasterCard)

$\square$ Check enclosed $\quad \square$ Please bill me

Orders may be placed with any bookshop, subscription agency, directly with the publisher or through a Karger distributor.
Fax: +41 613061234

S. Karger AG, P.O. Box, CH-4009 Basel (Switzerland)

E-Mail orders@karger.ch,www.karger.com

Name/Address: 


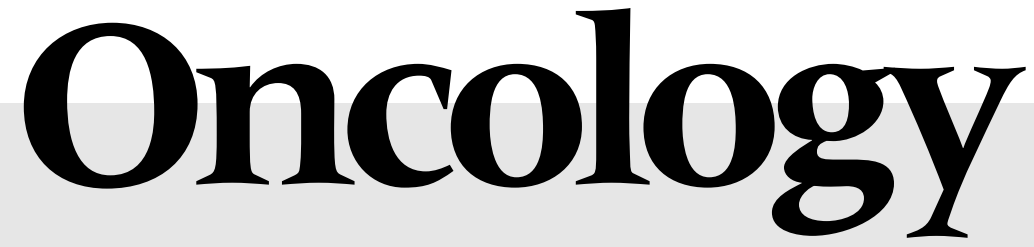

International Journal of Cancer Research and Treatment

Impact Factor: 2.538

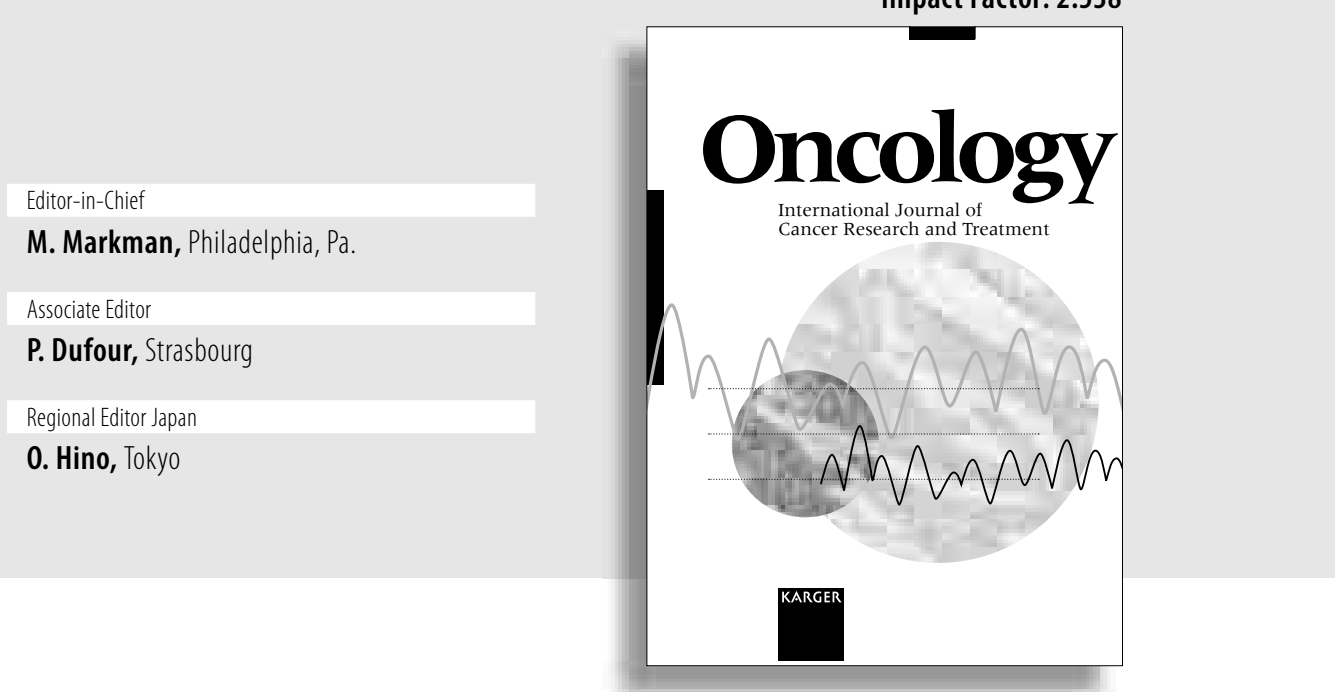

Although laboratory and clinical cancer research need to be closely linked, observations at the basic level often remain removed from medical applications. This journal works to accelerate the translation of experimental results into the clinic, and back again into the laboratory for further investigation. The fundamental purpose of this effort is to advance clinically-relevant knowledge of cancer, and improve the outcome of prevention, diagnosis and treatment of malignant disease. The journal publishes significant clinical studies from cancer programs around the world, along with important translational laboratory findings, mini-reviews (invited and submitted) and in-depth discussions of evolving and controversial topics in the oncology arena. A unique feature of the journal is a section which focuses on rapid peer-review and subsequent publication of short reports of phase 1 and phase 2 clinical cancer trials, with a goal of insuring that high-quality clinical cancer research quickly enters the public domain, regardless of the trial's ultimate conclusions regarding efficacy or toxicity.
Selected contributions

Prospective Multicenter Randomized Phase III Study of Weekly versus Standard Docetaxel plus Doxorubicin (D4) for First-Line Treatment of Metastatic Breast Cancer: Stemmler, H.-J.; Harbeck, N. (Munich); Gröll de Rivera, I. (Ebersberg); Vehling Kaiser, U. (Landshut); Rauthe, G. (Oberstaufen); Abenhardt, W.; Artmann, A.; Sommer, H. (Munich); Meerpohl, H.-G. (Karlsruhe); Kiechle, M.; Heinemann, V. (Munich)

Prognostic Factors in Small Cell Lung Cancer: A New Prognostic Index in Korean Patients: Hong, S.; Cho, B.C.; Choi, H.J.; Jung, M.; Lee, S.H.; Park, K.S.; Kim, S.K.; Kim, J.H. (Seoul)

Bevacizumab plus Irinotecan-Based Regimens in the Treatment of Metastatic Colorectal Cancer: Heinemann, V. (Munich); Hoff, P.M. (São Paulo)

Rechallenge with Platinum plus Fluoropyrimidine $+/$ - Epirubicin in Patients with Oesophagogastric Cancer: Okines, A.F.C.; Asghar, U.; Cunningham, D.; Ashley, S.; Ashton, J.; Jackson, K.; Hawkes, E.; Chau, I. (London)

Cisplatin Application in Pregnancy: First in vivo Analysis of 7 Patients: Marnitz, S.; Köhler, C. (Berlin); Oppelt, P. (Linz); Schmittel, A.; Favero, G.; Hasenbein, K.; Schneider, A. (Berlin); Markman, M. (Houston, Tex.)

Safety and Efficacy of Sorafenib in Elderly Patients Treated in the North American Advanced Renal Cell Carcinoma Sorafenib Expanded Access Program: Bukowski, R.M. (Cleveland, Ohio); Stadler, W.M. (Chicago, III.); McDermott, D.F. (Boston, Mass.); Dutcher, J.P. (Bronx, N.Y.); Knox, J.J. (Toronto, Ont.); Miller, W.H., Jr. (Montreal, Que.); Hainsworth, J.D. (Nashville, Tenn.); Henderson, C.A. (Atlanta, Ga.); Hajdenberg, J. (Orlando, Fla.); Kindwall-Keller, T.L. (Cleveland, Ohio); Ernstoff, M.S. (Lebanon, N.H.); Drabkin, H.A. (Charleston, S.C.); Curti, B.D. (Portland, Oreg.); Chu, L. (Sarasota, Fla.); Ryan, C.W. (Portland, Oreg.); Hotte, S.J. (Hamilton, Ont.); Xia, C. (Montville, N.J.); Cupit, L. (Wayne, N.J.); Figlin, R.A. (Duarte, Calif.)

A Randomized Phase II Study Comparing Two Schedules of the 21-Day Regimen of Gemcitabine and Carboplatin in Advanced Non-Small Cell Lung Cancer: Surmont, V. (Rotterdam/Ghent); Aerts, J.G.J.V. (Breda); van Klaveren, R.J. (Rotterdam); Tournoy, K. (Ghent); Tan, K.Y.; Vernhout, R.M.; Schmitz, P.I.M. (Rotterdam); Legrand, C. (Louvain-la-Neuve); Hoogsteden, H.C. (Rotterdam); van Meerbeeck, J.P. (Ghent)
More information at

\section{www.karger.com/ocl}

- Pay-per-View and Subscriber Access to Full Text

- Full Table of Contents

- Full Editorial Board

- Free Abstracts and Selected Articles

- Online Sample Issue

- Submission/Guidelines for Authors

- Subscription Details

- Free Alert Service

- Online Library Recommendation

\section{Oncology}

2012: Volumes 82,83

6 issues per volume

Language: English

ISSN 0030-2414 (print)

ISSN 1423-0232 (online)

Listed in bibliographic services, including Current Contents $\% /$ Life Sciences, MEDLINE, Biological Abstracts, EMBASE/Excerpta Medica 
Review

1 A Review of the Cytomorphology of Epstein-Barr Virus-Associated Malignancies

Michelow, P. (Johannesburg); Wright, C. (Cape Town); Pantanowitz, L. (Pittsburgh, Pa.)

Fine Needle Aspiration

15 Myxofibrosarcoma: Cytomorphologic Findings and Differential Diagnosis on Fine Needle Aspiration

Olson, M.T.; Ali, S.Z. (Baltimore, Md.)

25 Cytopathologic Analysis of Stroma-Poor Salivary Gland Epithelial/Myoepithelial Neoplasms on Fine Needle Aspiration

Chen, L.; Ray, N. (Cleveland, Ohio); He, H. (Beijing); Hoschar, A. (Cleveland, Ohio)

34 Pancreatic Cystic Lesions without Overt Cytologic Atypia: Proposed Diagnostic Categories for Endoscopic Ultrasound-Guided Fine-Needle Aspiration Cytology with Utilization of Fluid Carcinoembryonic Antigen Level

Madan, R.; Khan, E.; Cuka, N.; Olyaee, M.; Tawfik, O.; Fan, F. (Kansas City, Kans.)

41 The Accuracy of the 'Triple Test' in the Diagnosis of Papillary Lesions of the Breast

Papeix, G. (Taree, N.S.W.); Zardawi, I.M. (Newcastle, N.S.W.); Douglas, C.D.; Clark, D.A. (Gateshead, N.S.W.); Braye, S.G. (Newcastle, N.S.W.)

Gynecologic Cytopathology

47 World Wide Web-Based Cytological Analysis of Atypical Squamous Cells Cannot Exclude High-Grade Intraepithelial Lesions

Washiya, K. (Hirosaki); Takamizu, R. (Osaka); Kumagai, Y. (Hachinohe); Himeji, Y. (Shibata); Kobayashi, T. (Fukuyama); Iwai, M. (Otsu); Watanabe, J. (Hirosaki)

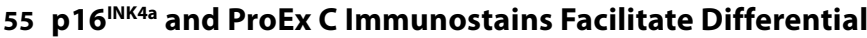
Diagnosis of Hyperchromatic Crowded Groups in LiquidBased Papanicolaou Tests with Menstrual Contamination

Ge, Y.; Mody, D.R. (Houston, Tex./New York, N.Y.); Smith, D. (Houston, Tex.); Anton, R. (Houston, Tex./New York, N.Y.)

Nongynecologic Cytopathology

62 Histopathologic Outcomes and Clinical Correlations for High-Risk Patients Screened with Anal Cytology Zhao, C.; Domfeh, A.B.; Austin, R.M. (Pittsburgh, Pa.)
Techniques

68 Exfoliative Cytology and Cytocentrifuge Preparation of Oral Premalignant and Malignant Lesions

Shah, P. (Belgaum); Deshmukh, R. (Pune)

74 Application of a New Liquid-Based Procedure (TACAS) for the Screening of Cervical Cancer: A Preliminary Study

Kuramoto, H.; Iwami, Y.; Sugimoto, N.; Kato, C.; Sugahara, T.; Iida, M. (Yokohama)

Molecular Techniques

80 Prevalence of Human Papilloma Virus in Esophageal Carcinomas: A Polymerase Chain Reaction-Based Study Gupta, N.; Barwad, A.; Rajwanshi, A.; Kochhar, R. (Chandigarh)

Novel Insights from Clinical Practice

85 Lymphoepithelioma-Like Carcinoma of the Breast: Cytological and Histological Features and Review of the Literature

Trihia, H.; Siatra, H.; Gklisty, H.; Diamantopoulos, P.; Arapantoni-Dadiotis, P.; Kalogerakos, K. (Piraeus)

92 Vaginal Stump Metastasis from Sigmoid Colon Cancer Tanaka, T.; Kanda, T.; Sakaguchi, S.; Munakata, S.; Ohmichi, M. (Osaka)

97 Fine-Needle Aspiration Cytology of Metastatic Oligodendroglioma: Case Report and Literature Review Can, B.; Akpolat, İ.; Meydan, D.; Üner, A.; Kandemir, B.; Söylemezoğlu, F. (Samsun)

104 The Chance Identification of Unusual-Appearing Bacteria in Bronchoalveolar Lavage Fluid Hearp, M.L. (Greenville, N.C.); Jakowski, J.D. (Richmond, Va.)

Letter to the Editor

107 Familial Adenomatous Polyposis-Associated Papillary Thyroid Carcinoma Shows an Indolent Course and Usually, but Not Always, Belongs to the CribriformMorular Variant of Papillary Thyroid Carcinoma Cetta, F.; Moltoni, L.; Barellini, L. (Siena); Monti, M. (Milan); Gotti, G. (Siena) 